\title{
Pengaruh Diameter Lubang Snifter-Valve Terhadap Peningkatan Tekanan Dalam Tabung Udara Pompa Hydram
}

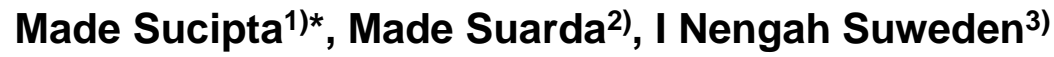 \\ 1,2)Jurusan Teknik Mesin Universitas Udayana, Kampus Bukit Jimbaran Bali \\ 3)Jurusan Teknik Elektro Universitas Udayana, Kampus Bukit Jimbaran Bali \\ Naskah diterima 19/08/2018; direvisi 04/04/2019; disetujui 30/04/2019 \\ doi: https://doi.org/10.24843/JEM.2019.v12.i01.p08
}

\begin{abstract}
Abstrak
Pompa hydram telah banyak diaplikasikan terutama di daerah pedesaan atau perbukitan dimana ketersediaan suplai energy listrik menjadi kendala. Pompa hydram adalah pompa mekanis yang memanfaatkan peningkatan tekanan (water hammer) yang terjadi akibat mekanisme penutupan katup limbah secara tiba-tiba. Untuk itu pada badan pompa hydram dipasang tabung udara untuk mengurangi denyutan aliran air hasil pemompaan. Dalam kurun waktu tertentu operasi pompa hydram, jumlah udara yang ada dalam tabung udara akan terus berkurang. Untuk menggantikan volume udara dalam tabung udara tersebut maka pompa hydram dilengkapi dengan katup penghirup udara (snifter-valve). Namun dalam implementasinya, katup ini hanya berupa lubang berdiameter $1 \div 2 \mathrm{~mm}$ pada jarak sekitar $2 \mathrm{~cm}$ di bawah katup tekan pada badan pompa hydram. Namun sampai saat ini belum ada acuan diameter lubang snifter-valve tersebut. Oleh sebab itu, pada penelitian ini diinvestigasi besarnya peningkatan tekanan yang terjadi dalam tabung udara pompa hydram. Pada penelitian ini pompa hydram dilengkapi dengan katup hirup dengan variasi diameter lubangnya yaitu 0,5, 1,0, 1,5, 2,0 dan 2,5 mm. Hasil penelitian menunjukkan bahwa pada model pompa hydram dengan pipa penggerak berdiameter $1 \frac{1 / 4}{4}$ inchi yang diuji, peningkatan tekanan yang terjadi dalam tabung udara berkisar antara 0,4 sampai dengan 0,5 bar. Snifter-valve dengan lubang berdiameter $1,5 \mathrm{~mm}$ menghasilkan peningkatan tekanan water hammer tertinggi dalam tabung udara sehingga memberikan kerja tertinggi yang terjadi dalam pompa hydram.
\end{abstract}

Kata kunci: pompa hydram, snifter-valve, diameter lubang katup, tabung udara, peningkatan tekanan

\section{Abstract}

Hydraulic ram pumps have been implemented and installed mainly in hilly or remote area where they are facing public electrical supply problem. Hydraulic ram pumps are mechanical pumps that utilize the increased water hammer due to the sudden shutdown mechanism of the waste valve. Therefore, the hydraulic ram pump is equipped with air vessel to reduce the pulsation of the pumping water flow. Within a certain period of hydraulic ram pump operation, the amount of air present in the air vessel will continue to decrease. In order to replace the air volume in the air vessel, the hydraulic ram pump is equipped with a sniftervalve. However, in its implementation, this valve is only a hole with a diameter of $1 \div 2 \mathrm{~mm}$ at a distance of about $2 \mathrm{~cm}$ below the delivery valve on the body of the hydraulic ram pump. However, there has not been any reference for determining the diameter of the snifter-valve hole yet. Therefore, in this study, works carried out for investigating the magnitude of the increased pressure that occurs in the air vessel of hydram pump. In this study, a hydraulic ram pump equipped with a snifter-valve with various orifice diameters of $0.5,1.0,1.5,2.0$ and $2.5 \mathrm{~mm}$. The results show that for the hydraulic ram pump model with $1 \frac{114}{4}$ inch diameter of the drive pipe that tested, the incrising pressure in the air vessel is about 0.4 up to 0.5 bar. The snifter-valve with $1.5 \mathrm{~mm}$ orifice diameter generates the highest incrising pressure of water hammer pressure in the air vessel, therefore, it gives the maximum work in the hydraulic ram pump.

Keywords: hydraulic ram pump, snifter-valve, orifice diameter, air vessel, incrising pressure

\section{Pendahuluan}

Pompa hydraulic ram (hydraulic ram) adalah perangkat yang memanfaatkan energi yang tersedia pada aliran terjunan air untuk memompa sebagian air tersebut ke tempat yang elevasinya lebih tinggi tanpa menggunakan energi listrik atau bahan bakar minyak $[1,2]$. Pompa hydraulic ram pertama kali dirancang di Inggris pada akhir abad ke-18 oleh John Whitehurst, yang aslinya diberi nama "pulsation engine". Desain generasi berikutnya dilakukan oeh Joseph Michel Montgolfier dan dipatenkan pada tahun 1797. Pompa hydraulic ram dalam sejarah perkembangannya digunakan sebagai peralatan irigasi untuk menyediakan air pada lokasi dimana energi listrik tidak tersedia. Keuntungan utama pompa hydraulic ram adalah strukturnya sederhana, menggunakan sumber energi terbarukan dan handal.
Komponen pompa hydraulic ram adalah bak suplai air, pipa penggerak, badan pompa, katup limbah (waste atau impulse valve), katup tekan (delivery valve), katup hirup udara (snifter valve), tabung udara, dan pipe penyalur [3]. Mekanisme kerja katup limbah tersebut mengakibatkan terjadinya palu air (water hammer) saat katup limbah tersebut menutup tiba-tiba. Energi tekanan palu air ini yang dimanfaatkan dalam siklus pompa hydraulic ram [4]. Katup limbah terutama berpengaruh pada besarnya gaya impulse yang dibangkitkan [5]. Pada operasi pompa hydraulic ram, dalam kurun waktu tertentu volume udara dalam tabung udara secara bertahap akan berkurang keluar bersama air hasil pemompaan untuk itu dibutuhkan suplai udara ke dalam badan pompa melalui katup hirup udara (snifter-valve).

\footnotetext{
${ }^{*}$ Korespondensi:

E-mail: m.sucipta@gmail.com
} 
Dalam implementasinya, katup snifter-valve ini umumnya hanya didesain berupa lubang berdiameter $1 \div 2 \mathrm{~mm}$ pada jarak sekitar $2 \mathrm{~cm}$ di bawah katup tekan pada badan pompa hydraulic ram, seperti pada Gambar 1. Hal ini akan dapat mengakibatkan berkurangnya tekanan water hammer yang terjadi karena terjadi kebocoran aliran melalui lubang tersebut sehingga akan dapat pula mengurangi unjuk kerja pompa hydraulic ram. Berdasarkan konsep kerjanya bahwa snifter-valve adalah katup anti vakum otomatis dimana akan menutup saat proses kompresi dan membuka saat recoil atau pressure back, maka konsep katup ini semestinya adalah katup satu arah (non-return valve atau check valve). Desain katup satu arah yang akan diinvestigasi pada penelitian tersebut adalah jenis katup yang berbentuk bola atau peluru. Bentuk bola dipilih mengingat bola lebih mudah gerak membuka dan menutupnya dibandingkan bentuk piringan (disc).

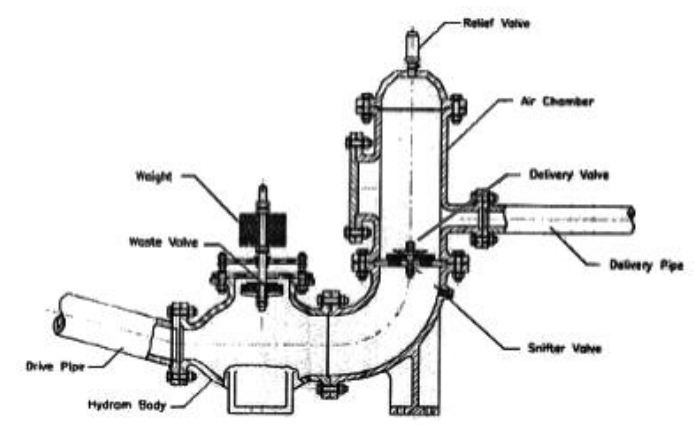

Gambar 1. Komponen - komponen utama pompa hydraulic ram [6]

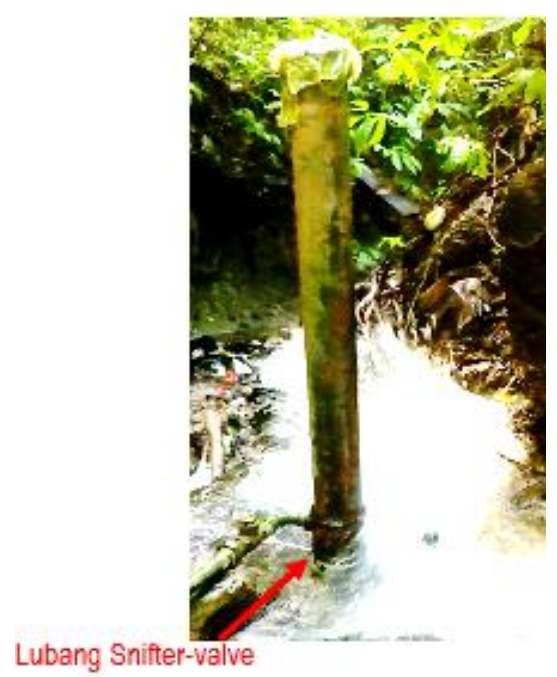

Gambar 2. Lubang snifter-valve pada pompa hydraulic ram

Pada awal siklus katup limbah terbuka dan katup tekan tertutup. Air mulai mengalir dari bak sumber air dan keluar melalui katup limbah ke atmosfir. Aliran air dipercepat akibat head air sumber secara gravitasi melalui pipa penggerak. Proses akselerasi ini terus berlangsung sampai suatu waktu dimana gaya dinamik atau gaya drag aliran pada katup limbah melebihi gaya berat katup limbah sehingga katup limbah tersebut tertutup.
Akibat menutup katup limbah dengan sangat cepat, mengakibatkan aliran air dalam pipa penggerak berhenti dengan tiba-tiba. Hal ini mengakibatkan peningkatan tekanan sebagai akibat penurunan kecepatan aliran air. Energi kinetik yang tersisa dirubah menjadi energi potensial dengan mendorong sejumlah air melewati katup tekan dengan melawan head penyaluran menuju ke dalam tabung tekan atau tabung udara. Selanjutnya mengkompresi udara yang ada di dalam tabung tersebut sampai kecepatan aliran air menjadi nol.

Udara di dalam tabung udara yang dikompresi tadi akan menekan air di dalam tabung tersebut ke dalam pipa penyalur dan berikutnya mengalir ke dalam reservoir. Ketika kecepatan aliran menjadi nol, katup tekan akan tertutup. Tekanan di dalam pipa penggerak turun sehingga mengakibatkan kecepatan negatif dan terjadi aliran balik dalam pipa penggerak. Pada saat tersebut udara akan terisap ke dalam badan pompa melalui snifter valve.

Selanjutnya tekanan di dalam badan pompa turun sehingga mengakibatkan katup limbah terbuka secara otomatis. Katup limbah terbuka dan aliran balik ke arah bak suplai air. Ketika katup limbah sudah tercelup, air akan terisap kembali dan mengalir melalui katup limbah. Jadi Siklus kerja pompa hydram terulang kembali.

Pada millenium kedua ini pompa hydraulic ram telah banyak digunakan oleh masyarakat. Suarda dan Sukadana telah mengimplementasikan pompa hydraulic ram dengan katup tekan model membran untuk memompa air untuk pelayanan masyarakat di desa Belantih kecamatan Kintamani kabupaten Bangli [7]. Disamping itu pompa hydraulic ram tersebut dibuat dengan konstruksi menggunakan sistem sambungan flange dan baut-mur untuk mempermudah dalam perakitan dan pembongkaran terutama dalam perbaikan katupnya. Sejalan dengan disain konstruksi tersebut, Yang mengajukan disain baru (novel) pompa hydraulic ram dengan catatan bahwa disarankan untuk tidak menggunakan pembesaran konis pada bagian katup limbahnya tetapi cambered diffuser dengan sudut antara $25^{\circ}$ dan $90^{\circ}$, untuk menghidari distribusi tekanan yang tidak simetris pada piringan katup limbah [8]. Mengingat pada pompa hydraulic ram hanya ada dua bagian yang bergerak, yaitu katup limbah dan katup tekan, yang desainya sangat menentukan performnasi pompa hydraulic ram, maka Suarda telah mengkaji gaya-gaya yang terjadi pada kedua katup tersebut dengan analisa aljabar [9]. Secara umum, metode yang dapat digunakan dalam pertimbangan utama perencanaan dan aplikasi dengan berbagai cara telah diusulkan oleh Balguda [10]. Namun, menurut Nambiar katup limbah merupakan komponen kunci utama dalam pompa hydraulic ram sehingga memerlukan perhatian dalam pengembangan dan optimasi lebih lanjut dalam peningkatan effisiensi total sistem pompa hydraulic ram [11].

Oleh sebab itu perlu dilakukan penelitian untuk mengiinvestigasi pengaruh diameter lubang sniftervalve pompa hydram terhadap peningkatan tekanan dalam tabung udara pompa hydram. Penelitian ini sangat penting dilaksanakan karena masih minimnya 
penelitian dan pengembangan disain pompa hydraulic ram, terutama referensi dalam penentuan dimensidimensi snifter-valvenya. Dengan disain snifter-valve yang lebih tepat diharapkan dapat dihasilkan unjuk kerja pompa hydraulic ram lebih optimal. Selanjutnya dengan tersedianya disain tersebut diharapkan dapat mengembangkan pembuatan dan pemanfaatan pompa hydraulic ram di masyarakat.

\section{Metode Penelitian}

\subsection{Rancangan Penelitian}

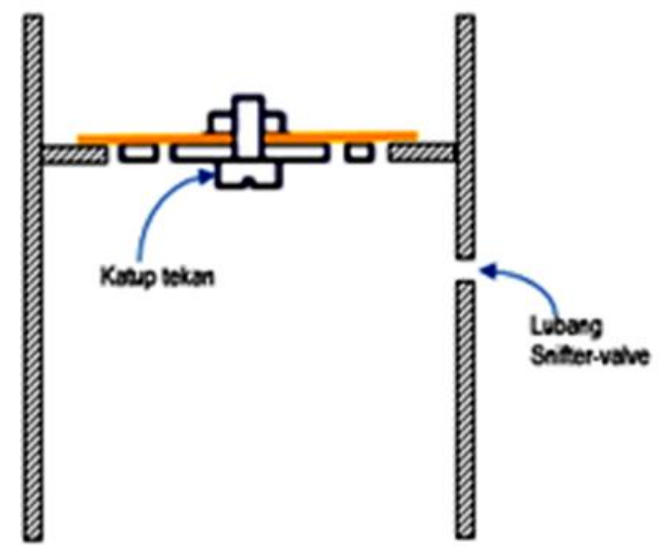

Gambar 3. Desain lubang Snifter-valve

Penelitian dilakukan untuk membandingkan unjuk kerja sistem pompa hydram dengan snifter-valve berupa lubang, seperti Gambar 3, dengan variasi diameter lubang yaitu 0 (tanpa lubang); 0,5; 1,0; 1,5; 2,0 dan 2,5 mm. Pengujian tersebut dilakukan secara eksperimen pada model pompa hydraulic ram yang telah terpasang di laboratorium Konversi Energi Jurusan Teknik Mesin FT-UNUD.

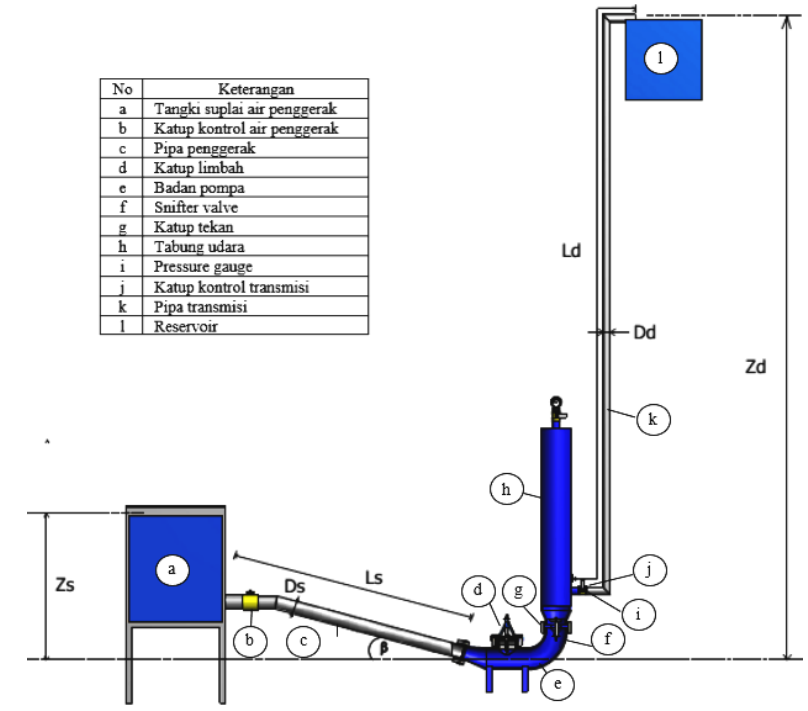

Gambar 4. Skema instalasi pengujian sistem pompa hydraulic ram

Pada penelitian ini pengujian eksperimental dilakukan pada sistem instalasi pompa hydraulic ram seperti pada Gambar 4. Penelitian ini dilakukan pada model pompa hydraulic ram dengan spesifikasi sebagai berikut:
1) Tinggi permukaan air ada bak penggerak (drive head), $\mathrm{Zs}=1.82 \mathrm{~m}$

2) Tinggi pemompaan (delivery head) $\mathrm{Zd}=2.02 \mathrm{~m}$, penambahan variasi delivery head diatur dengan mengatur bukaan katup kontrol pada pipa penyalur.

3) Diameter pipa penggerak $\mathrm{Ds}=36 \mathrm{~mm}$ dengan panjang $\mathrm{Ls}=12.2 \mathrm{~m}$.

4) Diameter pipa penyalur $\mathrm{Dd}=12 \mathrm{~mm}$ dengan panjang $1.36 \mathrm{~m}$.

5) Diameter piringan katup limbah adalah $47 \mathrm{~mm}$, dan panjang langkah $6.0 \mathrm{~mm}$.

6) Model snifter-valve: tanpa lubang, lubang diameter $1 \mathrm{~mm}$, dan check-valve dengan diameter oriffice 1 $\mathrm{mm}$.

7) Massa katup limbah (bagian yang bergerak) 490 gram

8) Volume tabung tekan $0.0083 \mathrm{~m}^{3}$.

Pengujian snifter valve pada sistem pompa hydraulic ram di laboratorium dilakukan melalui tahaptahap pengujian sebagai berikut:

Persiapan pompa dan alat bantu pengujian katup limbah, dengan ketinggian air suplai $Z s=1,82$ meter, diameter pipa penggerak $1 \frac{11 / 4}{4}$ inchi dan panjang $L s=9$ meter.

1) Setup pompa hydram dengan snifter-valve berupa tanpa lubang (berdiameter $0 \mathrm{~mm}$ ).

2) Setup ketinggian pemompaan $\mathrm{Zd}=2$ meter

3) Alirkan air ke bak penggerak sampai penuh dan dijaga dalam kondisi selalu over-flow supaya ketinggian head penggeraknya konstan

4) Buka katup kontrol suplai air penggerak, untuk mengalirkan air dari tangk suplai ke badan pompa.

5) Start kerja pompa dengan cara membuka dan menutup katup limbah agar pompa dapat bekerja dan biarkan pompa berjalan beberapa saat

6) Setup head tekanan pemompaan (Pd) 0,5 bar

7) Setelah pompa bekerja dan telah stabil lakukan pencatatan data seperti tinggi air pada V-notch weir (hvw) yang keluar dari katup limbah, waktu untuk volume air 10 liter yang keluar dari pipa penyaluran/delivery (Td), tekanan pada manometer pipa penyaluran air pemompaan $(\mathrm{Pd})$, dan frekuensi siklus kerja pompa (F).

8) Ulangi langkah 8 sebanyak 3 (tiga) kali

9) Ulangi langkah 7 sampai dengan 8 untuk head tekanan pemompaan (Pd): 1,0; 1,5; 2,0; dan 2,5 bar

10) Ulangi langkah 3 sampai dengan 10 untuk sniftervalve dengan variasi diameter lubang yaitu 1,0 , $1,5,2,0$ dan $2,5 \mathrm{~mm}$.

\section{Hasil dan Pembahasan}

Berdasarkan data hasil pengujian yang didapatkan dan kemudian dapat digambarkan seperti pada Gambar 5 sampai dengan Gambar 10. 


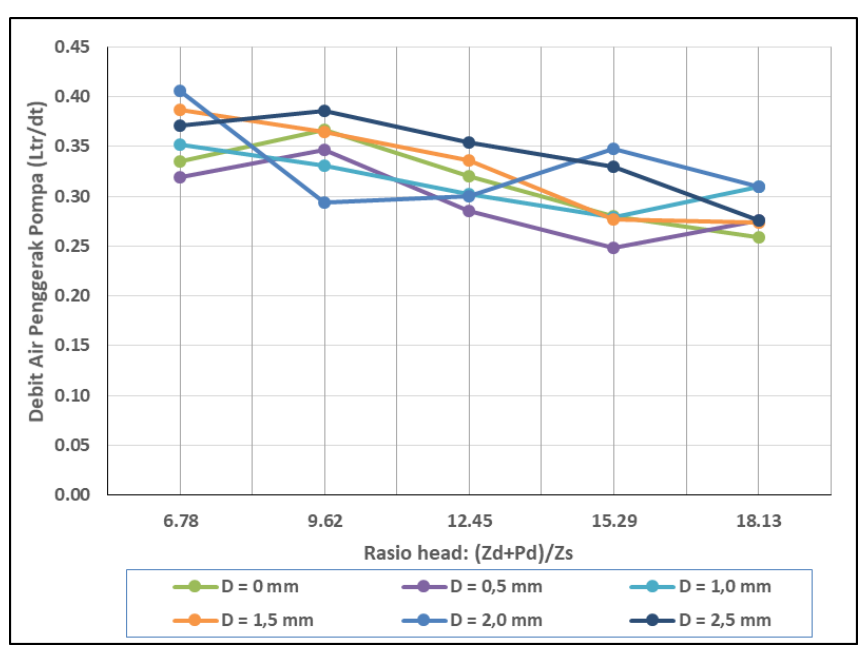

Gambar 5. Debit suplai penggerak pompa hydram

Semakin besar head pemompaan semakin kecil debit suplai air penggerak, dan Semakin besar diameter lubang Snifter-valve semakin kecil debit suplai air penggerak pompa hydram yang dibutuhkan. Hal ini disebabkan karena berkurangnya tekanan balik yang terjadi dalam pipa penggerak sebagai akibat semakin besarnya kebocoran tekanan air melalui snifter-valve.

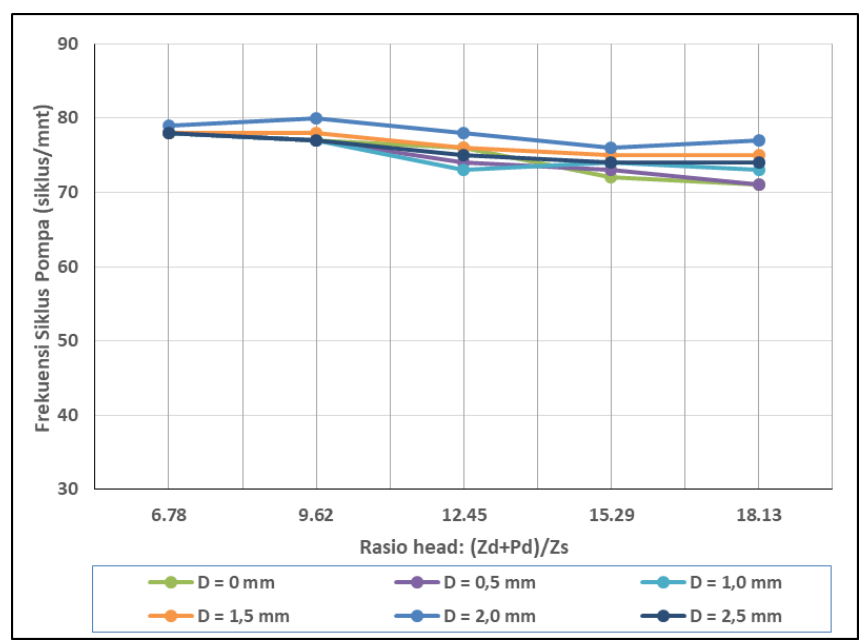

Gambar 6. Frekuensi siklus pompa hydram

Semakin besar head pemompaan semakin lambat siklus pemompaan yang terjadi, dan Semakin besar diameter lubang Snifter-valve mengakibatkan menurunnya frekuensi siklus pompa hydram. Hal ini disebabkan karena berkurangnya tekanan balik yang terjadi dalam pipa penggerak sebagai akibat semakin besarnya kebocoran tekanan air melalui snifter-valve.

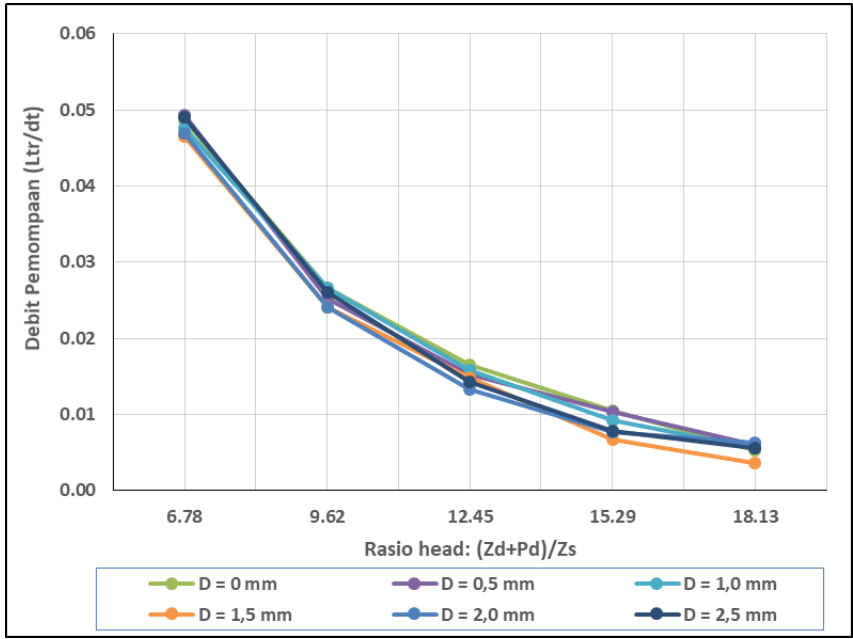

Gambar 7. Debit pemompaan pompa hydram

Secara umum semakin tinggi head pemompaan debit pemompaan pompa hydraulic ram semakin kecil, dan semakin besar diameter lubang snifter-valve debit pemompaannya relatif semakin kecil. Namun, Dengan snifter-valve berdiameter $0 \mathrm{~mm}$ (tanpa lubang) memberikan debit pemompaan paling tinggi. Namun, perlu dicatat bahwa untuk operasi pompa dalam kurun waktu tertentu jumlah udara dalam tabung tekan akan berkuran dan habis sehingga mengganggu operasi pompa bahkan berhenti beroperasi. Untuk itu Sniftervalve berdiameter $1 \mathrm{~mm}$ merupakan alternatif pilihan terbaik.

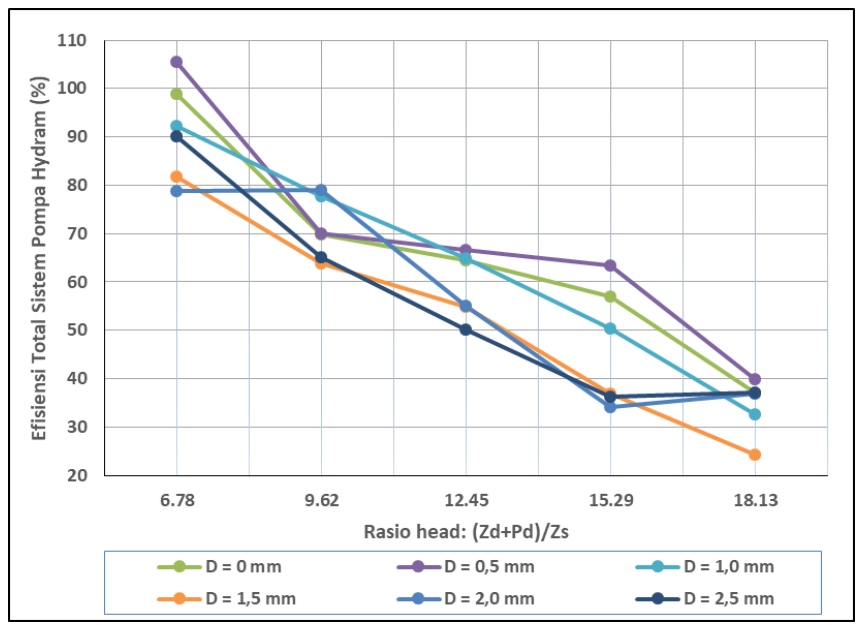

Gambar 8. Efisiensi total pompa hydram

Semakin tinggi head pemompaan semakin kecil efisiensi total pompa hydram yang dihasilkan. Disamping itu, semakin kecil diameter lubang Sniftervalve semakin tinggi efisiensi total yang dihasilkan. Mengingat fungsi snifter-valve maka snifter-valve dengan lubang berdiameter $0,5 \mathrm{~mm}$ sampai $1,0 \mathrm{~mm}$ merupakan alternatif pilihan terbaik. 


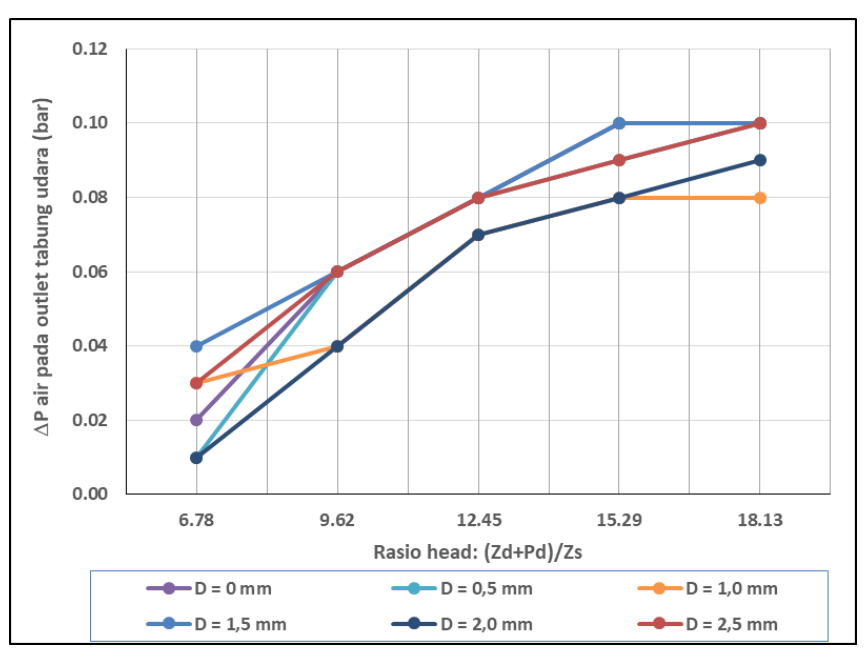

Gambar 9. Perubahan Tekanan pada pipa outlet pompa hydram

Semakin tinggi head pemompaan mengakibatkan semakin besar fluktuasi tekanan yang terjadi pada pipa outlet tabung tekan menuju pipa delivery, karena semakin tingginya head tekanan yang terjadi pada tabung tekan. Disamping itu, Snifter-valve yang berdiameter lubang kecil relatif mengakibatkan fluktuasi tekanan yang lebih besar.

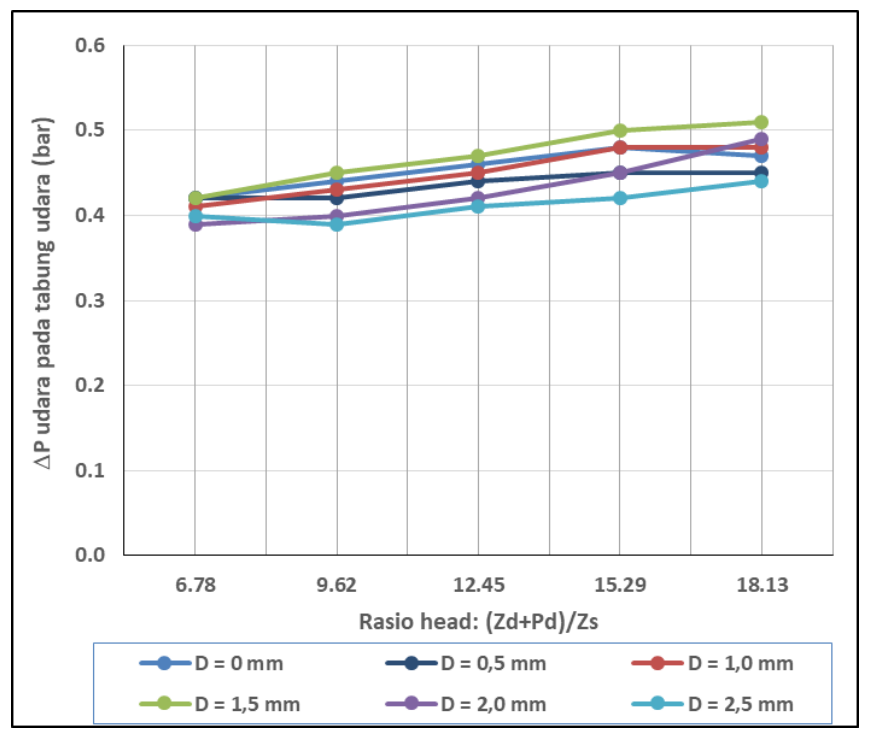

Gambar 10. Perubahan Tekanan Udara dalam tabung tekan pompa hydram

Semakin tinggi head pemompaan mengakibatkan semakin besar fluktuasi tekanan yang terjadi udara dalam tabung tekan pompa hydram, karena semakin tingginya head tekanan yang terjadi pada tabung tekan. Disamping itu, Snifter-valve yang berdiameter lubang kecil relatif mengakibatkan fluktuasi tekanan udara dalam tabung tekan pompa hydram, kecuali pada diameter lubang $1,5 \mathrm{~mm}$, namun, ini perlu diselidiki lebih lanjut.

\section{Simpulan}

Hasil penelitian menunjukkan bahwa pada model pompa hydram dengan pipa penggerak berdiameter $11 / 4$ inchi yang diuji, semakin kecil diameter lubang snifter-valve relatif memberikan debit pemompaan dan efisiensi total yang paling tinggi. Namun, perlu dicatat bahwa untuk operasi pompa dalam kurun waktu tertentu jumlah udara dalam tabung tekan akan berkuran dan habis sehingga mengganggu operasi pompa bahkan berhenti beroperasi. Oleh sebab itu, Snifter-valve berdiameter $1 \mathrm{~mm}$ merupakan alternatif pilihan terbaik. Selanjutnya, peningkatan tekanan yang terjadi dalam tabung udara berkisar antara 0,4 sampai dengan 0,5 bar. Snifter-valve dengan lubang berdiameter $1,5 \mathrm{~mm}$ menghasilkan peningkatan tekanan water hammer tertinggi dalam tabung udara sehingga memberikan kerja tertinggi yang terjadi dalam pompa hydram.

Namun, perlu dipertimbangkan diamater lubang snifter-valve yang lebih besar untuk sistem pompa hydram yang lebih besar mengingat dimensi pipa penggerak dan tabung udaranya juga lebih besar. Untuk itu dibutuhkan penelitian lebih lanjut pada variasi diameter badan pompa hydram dan pipa penggeraknya. Disamping itu, perlu dilakukan pengujian pada periode waktu yang lebih lama, misal satu minggu atau lebih untuk mengetahui pengurangan atau penambahan volume udara pada tabung udara pompa hydram.

\section{Ucapan Terima Kasih}

Ucapan terima kasih disampaikan kepada Fakultas Teknik Universitas Udayana dan Lembaga Penelitian dan Pengabdian kepada Masyarakat Universitas Udayana atas dukungan pendanaan penelitian yang telah diberikan dalam skim Penelitian Unggulan Udayana tahun 20178

\section{Daftar Pustaka}

[1] E. Celik, "Interactive Ram Pump Display Project", in International Mechanical Engineering Congress \& Exposition - IMECE2012, November 9-15, 2012, Proceedings of the ASME 2012, (The American Society of Mechanical Engineers, Houston, Texas, 2012), pp 1-10.

[2] M. Inthachot, S. Saehaeng, J.F.J. Max, J. Müllerc and W. Spreer, "Hydraulic Ram Pumps for Irrigation in Northern Thailand", in Agriculture and Agricultural Science Procedia Vol. 5 (2015), (Elsevier B.V., 2015), pp.107-114.

[3] P. Diwan, A. Patel and L. Sahu, "Design and Fabrication of Hydraulic Ram with Methods of Improving Efficiency", in International Journal of Current Engineering and Scientific Research (IJCESR), Vol. 3, No. 4, (Technical Research Organization India, 2016), pp. 5-13.

[4] A. Pathak, A. Deo, S. Khune, S. Mehroliya and M.M. Pawar, 2016. "Design of Hydraulic Ram Pump", in International Journal for Innovative Research in Science \& Technology, Vol 2, No. 10, (IJIRST, 2016), pp. 290-293.

[5] A. Deo, A. Pathak, S. Khune and M.M. Pawar, "Design Methodology for Hydraulic Ram Pump", in International Journal for Innovative Research in Science \& Technology, Vol 5, No. 4, (IJIRST, 2016), pp. 4737- 4745.

[6] A.A. Tessema, "Hydraulic Ram Pump System Design and Application", in ESME 5th Conference 
on Manufacturing and Process Industry. September 2000, (ESME, Addis Ababa, Ethiopia, 2000).J. van der Geer, J.A.J. Hanraads, R.A. Lupton, The art of writing a scientific article, J. Sci. Commun. 163 (2000) 51-59.

[7] M. Suarda, dan I K.G. Sukadana, "Perancangan dan Pengujian Unjuk Kerja Katup Tekan Pompa Hydraulic ram Model Plat, Membran, Bola dan Setengah-Bola", Prosiding: Seminar Nasional Tahunan Teknik Mesin (SNTTM - XII). Hal. 387 394. Bandar Lampung, 22-23 Oktober 2013.

[8] K.L. Yang, at. al., "Design and Hydraulic Performance od a Novel Hydraulic ram", 11th International Conference on Hydroinformatics, New York City, 8 January 2014, paper no 108.

[9] M. Suarda, "Forces Analysis on a Spherical Shaped Delivery Valve of Hydraulic ram Pump", in Applied Mechanics and Materials, Vol 776, (Trans Tech Publications, Switzerland, 2015), pp 377383.

[10] R.D. Balguda, et al., "Designing of Hydraulic Ram Pump", in International Journal of Engineering and Computer Science, Vol 4, No 5, (IJECS Publication, Madhya Pradesh, India, 2015), pp. 11966-11971.

[11] P. Nambiar, A. Shetty, A. Thatte, S. Lonkar and V. Jokhi, 2015." Hydraulic Ram Pump Maximizing efficiency", in International Conference on Technologies for Sustainable Development (ICTSD), 4-6 Feb. 2015, Mumbai - India, (IEEE Explore Digital Library, 2015).

[12] T. Taye, "Hydraulic Ram Pump", in Journal of the ESME. Vol. II, Juli 1998, (ESME, Addis Ababa, Ethiopia, 1998). 